
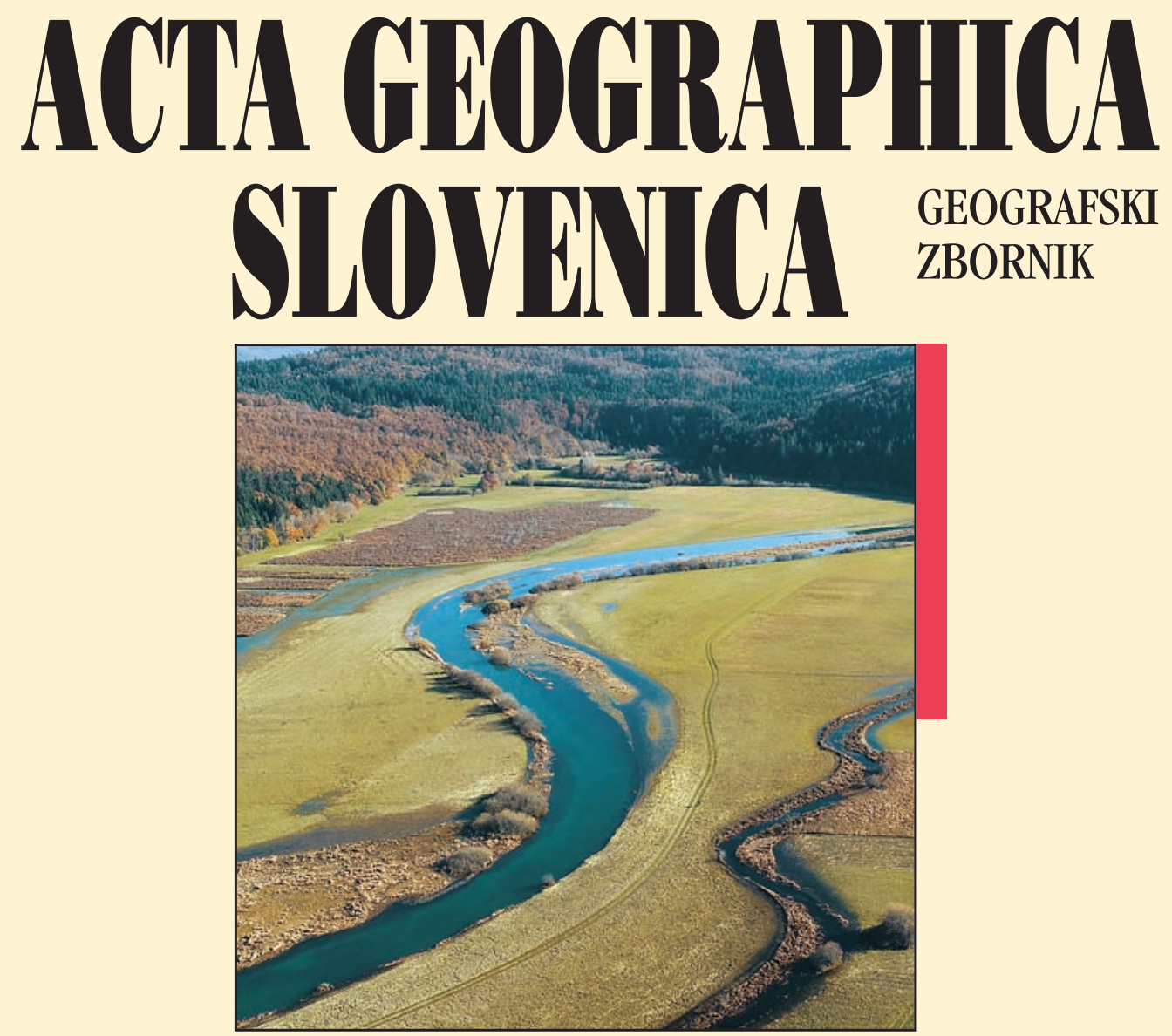


\section{ACTA GEOGRAPHICA SLOVENICA GEOGRAFSKI ZBORNIK \\ 61-1 - 2021}

\section{Contents}

Danijela STRLE, Matej OGRIN

Latent cooling of atmosphere as an indicator of lowered snow line: Case study from Planica and Vrata valleys

Vera GRAOVAC MATASSI, Ana TALAN

Recent marriage and childbearing trends in Croatia and Slovenia: A comparative review

Constantin NISTOR, Ionuț SĂVULESCU, Bogdan-Andrei MIHAI, Liliana ZAHARIA, Marina VÎRGHILEANU, Sorin CARABLAISĂ

The impact of large dams on fluvial sedimentation: The Iron Gates Reservoir on the Danube River

Jolanta JÓŹWIK, Dorota DYMEK

Spatial diversity of ecological stability in different types of spatial units: Case study of Poland

Danijel IVAJNŠIČ, David PINTARIČ, Veno JAŠA GRUJIĆ, Igor ŽIBERNA

A spatial decision support system for traffic accident prevention in different weather conditions

\section{Special issue: Gastronomy, territory and tourism}

Nika RAZPOTNIK VISKOVIĆ, Blaž KOMAC

Gastronomy tourism: A brief introduction

Maja TOPOLE, Primož PIPAN, Primož GAŠPERIČ, Matjaž GERŠIČ, Peter KUMER

Culinary events in the Slovenian countryside: Visitors' motives, satisfaction, and views on sustainability

Mateja ŠMID HRIBAR, Nika RAZPOTNIK VISKOVIĆ, David BOLE

Models of stakeholder collaboration in food tourism experiences

Carlos FERNANDES, Greg RICHARDS

Developing gastronomic practices in the Minho region of Portugal

Špela LEDINEK LOZEJ

Labelling, certification and branding of cheeses in the southeastern Alps (Italy, Slovenia):

Montasio, Bovec, Tolminc and Mohant cheese

Saša POLJAK ISTENIČ, Jasna FAKIN BAJEC

Luxury food tour: Perspectives and dilemmas on the »luxurification" of local culture

in tourism product

Nika RAZPOTNIK VISKOVIĆ

Gastronomy as a social catalyst in the creative place-making process

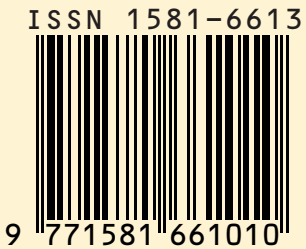




\section{LUXURY FOOD TOUR: PERSPECTIVES AND DILEMMAS ON THE »LUXURIFICATION« OF LOCAL CULTURE IN TOURISM PRODUCT}

Saša Poljak Istenič, Jasna Fakin Bajec

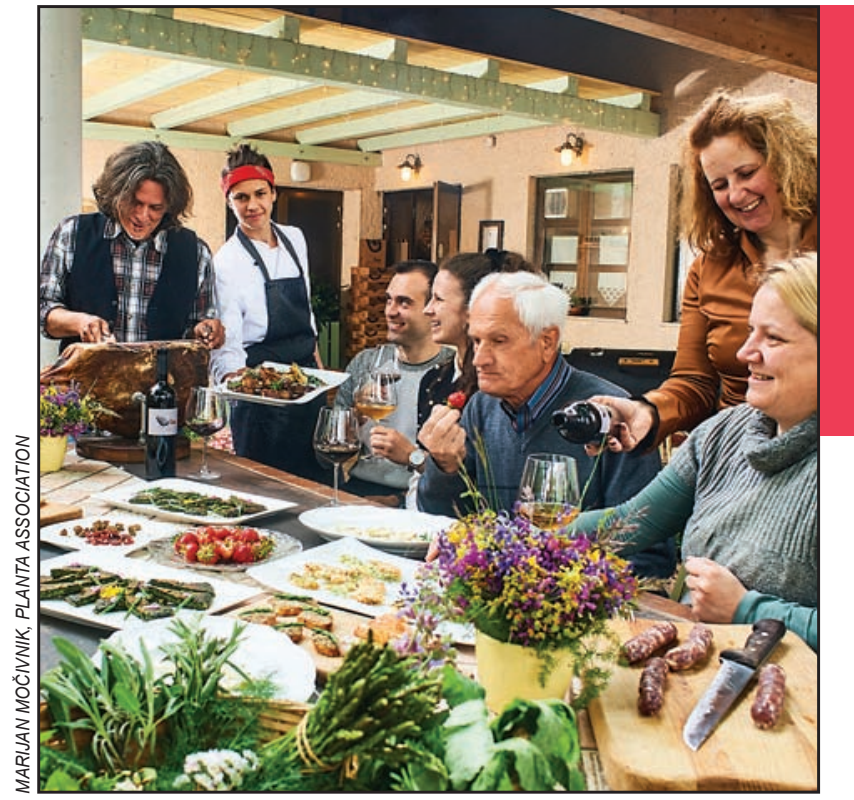

Luxury cuisine served by the local inhabitants on the Karst/Carso Food Tour. 
DOI: https://doi.org/10.3986/AGS.8960

UDC: $338.48: 641 / 642(497.4 \mathrm{Kras})$

COBISS: 1.01

Saša Poljak Istenič ${ }^{1}$ Jasna Fakin Bajec ${ }^{2}$

\title{
Luxury food tour: Perspectives and dilemmas on the "luxurification " of local culture in tourism product
}

\begin{abstract}
This paper focuses on the Kras/Carso Food Tour to present the challenges of developing a luxury tourism product. The tour's design followed the current strategy of the Slovenian Tourist Board, which defines specific criteria for a luxury experience. Contextualized by the experiential trends in tourism, the paper juxtaposes the bottom-up and top-down perspectives on luxury experiences. The authors argue that mediation by experts familiar with academic discourses and local culture is beneficial for the development of a successful tourism product. The study contributes to the debates on luxury tourism, which have neglected bottom-up perceptions in tourist discourse and overlooked the dilemmas people face when »luxurifying " their traditions and heritage practices.
\end{abstract}

KEY WORDS: experiential tourism, luxury tourism products, gastronomy, local culture, heritage, Kras/Carso Food Tour, Karst region

\section{Luksuzno gastronomsko doživetje: vidiki in dileme predelave lokalne kulture v luksuzni turistični izdelek}

POVZETEK: Članek se osredinja na gastronomsko doživetje Kras/Carso Food Tour, da predstavi izzive razvoja luksuznega turističnega izdelka. Zasnova doživetja je sledila trenutni strategiji Slovenske turistične organizacije, ki je opredelila posebna merila za luksuzno izkušnjo. Članek, ki je umeščen v izkustvene trende v turizmu, sopostavlja poglede na luksuzne izkušnje od spodaj navzgor in od zgoraj navzdol. Avtorici argumentirata, da je posredovanje strokovnjakov, ki poznajo akademske diskurze in lokalno kulturo, ključnega pomena za razvoj uspešnega turističnega izdelka. Študija prispeva k razpravam o luksuznem turizmu, ki so doslej zanemarjale vidike turističnega diskurza od spodaj navzgor in spregledale dileme, s katerimi se ljudje soočajo pri preobrazbi svojih tradicij in dediščinskih praks v luksuzne izdelke za turizem.

KLJUČNE BESEDE: izkustveni turizem, luksuzni turistični izdelki, gastronomija, lokalna kultura, dediščina, Kras/Carso Food Tour, Kras

The paper was submitted for publication on August $19^{\text {th }}, 2020$.

Uredništvo je prejelo prispevek 19. avgusta 2020.

Research Centre of the Slovenian Academy of Sciences and Arts, Institute of Slovenian Ethnology, Ljubljana, Slovenia

sasa.poljak@zrc-sazu.si (https://orcid.org/0000-0001-5277-7100)

Research Centre of the Slovenian Academy of Sciences and Arts, Institute of Culture and Memory

Studies, Nova Gorica, Slovenia

jasna.fakin@zrc-sazu.si (https://orcid.org/0000-0003-1680-6220) 


\section{Introduction}

»Luxury is no longer the embrace of kings and queens but the mass marketing phenomenon of everyday life. Simply put, luxury has become luxurification of the commonplace, « wrote futurologist Ian Yeoman $(2008,238)$ more than a decade ago when describing future scenarios and trends in tourism. This tourism orientation later intensified, leading some researchers to describe it as »the luxury turn " (Bellini and Resnick 2018). Countries, including Slovenia, quickly embraced the trend; the current Strategy for the Sustainable Growth of Slovenian Tourism 2017-2021 (MGRT 2017, 13) envisions the country as a "global green boutique destination for demanding guests who are seeking a diverse and active experience, peace of mind and personal benefits «. The phrase coined to denote products for »demanding guests « has become »fivestar experiences", which have been marketed under the quality label Slovenia Unique Experiences; similar "premium experience " labels were also adopted by other countries, regions or companies. Such brands characterize what is considered luxury in a tourism sense: local, authentic, unique, experiential, boutique, and sustainably green offerings of premium quality that address people able to afford it and provide them with a special, rare "experience».

In the late 1990s, after several researchers had already indicated this new, experiential orientation of the industry (Toffler 1970) and marketing (Holbrook and Hirschman 1982) as well as underlined the mental shift towards experiencing a quality life (Schulze 1992), Pine and Gilmore (1998; 1999) coined the term experience economy for the fourth stage of economic development (after the agrarian, industrial, and service economies). They argued that memorable events, or experiences, are a new recipe for business success. The concept was later adapted to numerous other fields, including tourism, where the experience was already recognized as its crucial aspect, especially regarding the notion of authenticity (Cohen 1979; Pearce and Moscardo 1986; Cohen 1988; Wang 1999; Bajuk Senčar 2005; Lew 2011; Manley et al. 2020). As a result, tourists began to be understood as active economic actors involved in the consumption of experiences while the crucial role of the tourism sector became to assist tourists in the production and the achievement of their experiences (Batat and Frochot 2014).

Experiential Tourism is thus not as new as we might suppose from the Slovenian Tourist Board's (STB) current strategy and orientation of Slovenian tourism. Defined as the opposite of mass tourism, it was described as a rapidly emerging trend in tourism as early as at the turn of the century (Prentice, Witt and Hamer 1998) and has since encompassed many types of tourism (Smith 2006), such as cultural tourism (Richards 1996; Du Cros and McKercher 2020; Timothy 2020), creative tourism (Richards 2011; Tan, Kung and Luh 2013; Poljak Istenič 2015; de Bruin and Jelinčić 2016; Richards 2020), ecotourism (Stronza 2001; Kozorog 2009; Fennell 2020), educational tourism (Ritchie, Carr and Cooper 2003; McGladdery and Lubbe 2017), experimental tourism (Antony and Henry 2005), heritage tourism (Kirshenblatt-Gimblett 1998; Timothy and Boyd 2003; Poljak Istenič 2013; Jelinčić and Senkić 2017; Kumer et al. 2019; Topole and Pipan 2020), nature or wildlife tourism (Curtin 2005; Kozorog and Poljak Istenič 2013; Sotiriadis 2017), and luxury tourism (Conrady, Ruetz and Aeberhard 2020). Besides its focus on active participation (or »immersion «) of tourists, the key components include environmental sensitivity, respect for local culture and people, and learning.

The luxury trend is especially on the rise in gastronomy and gastronomy tourism (Barrère, Bonnard and Chossat 2014; Bellini and Resnick 2018; Batat 2020). This is very obvious in Slovenia, the winner of the European Region of Gastronomy 2021 title. The first-ever Michelin Stars in the country were revealed in 2020. Chefs, restaurants, guest farms, and other organizations or initiatives pursue similar endeavours towards luxury. They organize top culinary events, wine, beer, or other festivals, participate in television cooking shows where the luxury culinary offer is promoted, etc.

Consequently, the level of culinary offerings in Slovenian restaurants and guest farms has risen sharply. As a result, gastronomy has become a key feature of Slovenia's tourism, supported by Slovenia's green orientation (Poljak Istenič 2016; Poljak Istenič 2018) as a promotional approach and certification scheme (such as Green Cuisine for gastronomy tourism). The promotion focuses on unique culinary experiences, especially those winning the label Slovenia Unique Experiences. As noted by Novak (2019), they give tourists "an opportunity to connect with the place they are visiting on many levels - physical, emotional, experiential, spiritual, intellectual and social «. This label also inspires tourism providers to »repack « their regular offers into luxury language and adapt to the eligibility and content criteria to apply for the brand (see Table 1).

Despite a thorough explanation of the criteria by the STB, some terms and concepts are utilized which are often disputed in the academic discourses of different disciplines (perhaps most of all authenticity; MacCannell 1976; Rickly and McCabe 2017). At the same time, they allow for a certain level of subjec- 
tivity and bias in their assessment and understanding, as was revealed in the case study of the Kras/Carso Food Tour, which forms the core of this paper. The authors were actively engaged in the process of the tour formation and its assessment. In this paper, they juxtapose top-down criteria for luxury experience, as defined by the national tourism organization (STB), with the bottom-up perceptions and understandings. The aim is to reflect on the discrepancies between bottom-up and top-down perspectives on the luxury experiences and analyse dilemmas linked to the inclusion of local culture in tourism according to the popular trends of luxury experiential tourism. The authors argue that understanding the key concepts in the criteria is challenging for tourism providers, and the mediation of experts familiar with academic discourses and local culture is thus beneficial for developing successful tourism products. The applied aim of the paper is to provide recommendations to tourism providers who would like to apply for Slovenia Unique Experiences or similar labels, but also inform the creators of labels on the problems of tourism providers to fulfil the criteria. The study contributes to the debates on luxury tourism, which have neglected bottom-up perceptions in tourist discourse and overlooked the dilemmas people face when »luxurifying « their traditions and heritage practices.

The authors first present the methodology of the study, provide analysis of a bottom-up understanding of top-down concepts, evaluate the designed culinary tour according to the top-down content criteria, and in conclusion highlight the need to consider bottom-up perspectives not only for successful design and implementation of luxury tourist experiences, but also for academic debates on the future of gastronomy tourism.

\section{Methods}

\subsection{Designing the tour}

The research was carried out in the framework of the Interreg project MEDFEST: Culinary heritage experience: how to create sustainable tourist destinations (2016-2019), led by ZRC SAZU (Anton Melik Geographical Institute). The project aimed to design culinary experiences to promote sustainable rural destinations (Internet 1). In Slovenia, the work was focused on the Karst region. The cultural landscape of the Karst, a limestone plateau in western Slovenia, is defined by numerous natural elements and processes (e.g., areas without water, underground water, caves, the bora wind, karst commons (gmajna - a mosaic of meadows, former pastures and forest edges with botanical species), etc.). Disadvantageous living conditions caused the development of a specific way of life, strongly characterized by stone elements and structures (e.g., dry stone, shepherds' cottages, houses, architectural details). This has created a particular landscape image today intensely used in tourism (Ciglič et al. 2012; Fakin Bajec 2015). The Karst-Brkini destination, a rural hinterland area where the research was situated, lags behind the nearby coastal region. Škocjan caves, Lipica stud farm, fortified historical village Štanjel, and the Karst edge are the key tourism attractions. Other heritage sites mostly revive during thematic festivals (the Teran and Prosciutto Festival, the Lavender Festival, the Karst Gmajna Festival, etc.). Gastronomy providers are also included in local cycling or hiking tours or other tourism offers (Fakin Bajec 2011; CPOEF 2018).

ZRC SAZU researchers involved in the MEDFEST project collaborated with the Planta Association for the Development of Agriculture and Tourism in the Karst Region. Its members were already working on a new culinary experience and needed the experts' help to enrich the activities and put the tourism product into practice. The Komenski Kras Tourist Organization was also involved in the project's pilot action. The researchers worked intensively with eight members of the Planta Association. Following the participatory research on culture-based development (Nared and Bole 2020; Fakin Bajec 2020a), they actively involved different stakeholders in developing activities from the beginning of the pilot action. The researchers conducted semi-structured interviews with members of the association, who came from three Karst restaurants (identified as R1, R2, R3), two tourist businesses (i.e., two guest farms, identified as GF1, GF2), and three farms producing various products (wine, prosciutto and other dried meat, cheese; F1, F2, F3). The main purposes of the interviews, conducted in April and May 2019, were to recognize the history of their restaurants, farms and/or villages, the structure of current guests, their culinary offer, the philosophy of their cuisine, the promotion of Karst cuisine, and the way they promote themselves and collaborate with the local population and associations. At the end of the conversations, the interviewees were also invited to express their wishes, expectations and ideas for the development of new luxury culinary experiences. 
During the discussions, the researchers asked the interlocutors to explain the terms used in the criteria for being awarded the Slovenia Unique Experiences label, such as »tourist experience«, »authenticity«, »sustainability«, »heritage«, and »traditions «. In this way, the researchers could better understand the perceptions, interests, and demands of the association's members, which helped them develop luxury culinary experiences. The interviews were then transcribed and used by one of the paper authors to create the content and slogans of the culinary tour. For the purpose of this paper, the authors analysed them with attention to interlocutors' understanding of the concepts mentioned above. The aim of the analysis was to reveal bottom-up perspectives on luxury gastronomy tourism.

The researchers then organized an interactive workshop for the local tourism providers they have interviewed to present the results of the ethnographic research and design thematic culinary experiences that would sustainably promote, preserve and develop the local culinary offerings based on tradition but adapted to innovative demands. Finally, after a year of additional work with the tourism providers, the »Kras/Carso Food Tour: A Unique Journey into Experiencing the Taste of the Authentic Karst « was created and presented to a broader public. In the end, four sub-thematic tours were designed (described in section 3.1), all promoted under the common label Kras/Carso Food Tour (Internet 2).

\subsection{Testing and evaluating the tour}

Seven experts from different fields (tourism, ethnology, geography, economics, architecture) were invited to test and evaluate the tour when it was designed (at the end, the driver of the test tour was also included in the evaluation). One of the authors of this paper participated in the test tour and, for the purpose of this paper, analysed it according to the criteria set up by the STB for its label Slovenia Unique Experiences. These criteria were chosen for the evaluation because the Planta Association intends to promote it as luxury gastronomy tourism and apply for this label in the future.

According to the criteria (Novak 2018; Internet 3), the experience must reflect the local identity and promote it through a story. Since the best promoters of identity are usually the local inhabitants, it is recommended that the tourists interact with them. The tourism products shall also include local gastronomy and souvenirs as material representations of the locality. The criterion of authenticity implies that the experience represents nature, culture (cultural heritage, way of life, cultural industries) and people of the region but not in a staged way or copying other tourism destinations. It should also highlight the area's uniqueness, represented by natural features, cultural offerings, accommodation, and adrenaline experiences. A strong experiential note is given when the tour provides a positive emotional, multi-sensory, and active experience, allowing the visitors not merely to monitor, visit or see but to cooperate, become immersed in, and learn about the local culture. The packages must also ensure all the aspects of sustainable (green) management. Targeting small groups and using a personal approach ensure that tourists have a boutique (and not mass) experience. A premium offer is ensured by quality schemes (e.g., Slovenian Green Cuisine), training for all the tourism workers, and cleanliness standards. The experience creates an added value by appealing to the visitors willing to pay more and ensuring that financial assets stay in the local community. The tourism product should not be limited only to summer (deseasonalization) and must contribute to the STB's strategy of turning Slovenia into a green boutique destination for a five-star experience (this criterion was later replaced by good digital experience; STB 2020).

Based on participant observation during the test tour, a qualitative evaluation was performed to assess how the tourism providers, with the help of experts, understood the top-down luxury criteria defined by the STB and succeeded in implementing them for a food tour design. The results of the evaluation of one of the paper's authors are presented in Table 1.

\section{Results and discussion}

\subsection{Bottom-up perspectives on luxury experiences}

The Kras/Carso Food Tour promotes Karst nature and local cuisine (ingredients, dishes, traditions, knowledge and tastes). It encompasses diverse experiences that provide tourists with hands-on learning about Karst cuisine and related phenomena, such as landscape, plant gathering, agriculture, culinary traditions, and family histories. The providers follow various approaches; some have built on family traditions, others 
have developed high-quality cuisine, while some have designed new tourism products. The biggest challenge for the experts and the Planta members was how to ensure a «premium «, »boutique«, and »authentic" experience with "added value « and other features defined in the STB's criteria that would not only make the culinary tour eligible for the label but also distinguish it from the luxury culinary experiences offered by other Slovenian operators.

There is a general agreement that the Karst landscape is unique because of its geological and related cultural features (classical Karst is thus also included on UNESCO's Tentative List for World Heritage; UNESCO 2020). However, the ZRC SAZU researchers, as well as the members of the Planta Association, struggled to determine how to demonstrate this uniqueness through culinary packages. Following the increasing orientation towards tourism experience and the impact of the luxury turn in gastronomy, the president of the Planta Association, who manages a guest farm, stressed that:

"Foreigners are extremely enthusiastic about all this [Slovenian culture]. If you take a foreigner to your farmstead and he feels he has been received heartily, he is delighted. /.../ Sitting here, sitting in the shade of the vine, and being able to look at it - he is already satisfied with that. /.../ When you take them to the field, it is already an experience. When you bring them here in this courtyard, it also makes a difference." (GF 1)

The other guest farm whose owner was interviewed served as an inn for horse and cart drivers (furmani) in the $19^{\text {th }}$ and the first half of the $20^{\text {th }}$ century. The discussion revolved around what could be prepared and offered to surprise the tourists, as this is one of the requirements for a memorable experience (Novak 2018). The interviewee suggested driving the guests in a horse carriage through a nearby town and »stopping by the traffic lights ( GF 2). On the other hand, for the chef of a top restaurant, the element of surprise is the use of heritage in an unusual way. They serve soup to the guests in a whetstone holder (oselnik):

"... an ox horn, which was once used as a tool for manually mowing grass. The horn was put on the back of the mower, and inside were vinegar and a whetstone for sharpening the scythe. [...] Well, now we have adapted it to pour the soup [on the plate]. We only put dumplings, a beef tail, a little celery, and carrots on the plate - what gets cooked in the soup - and then pour soup over it. This makes a difference." (R1)

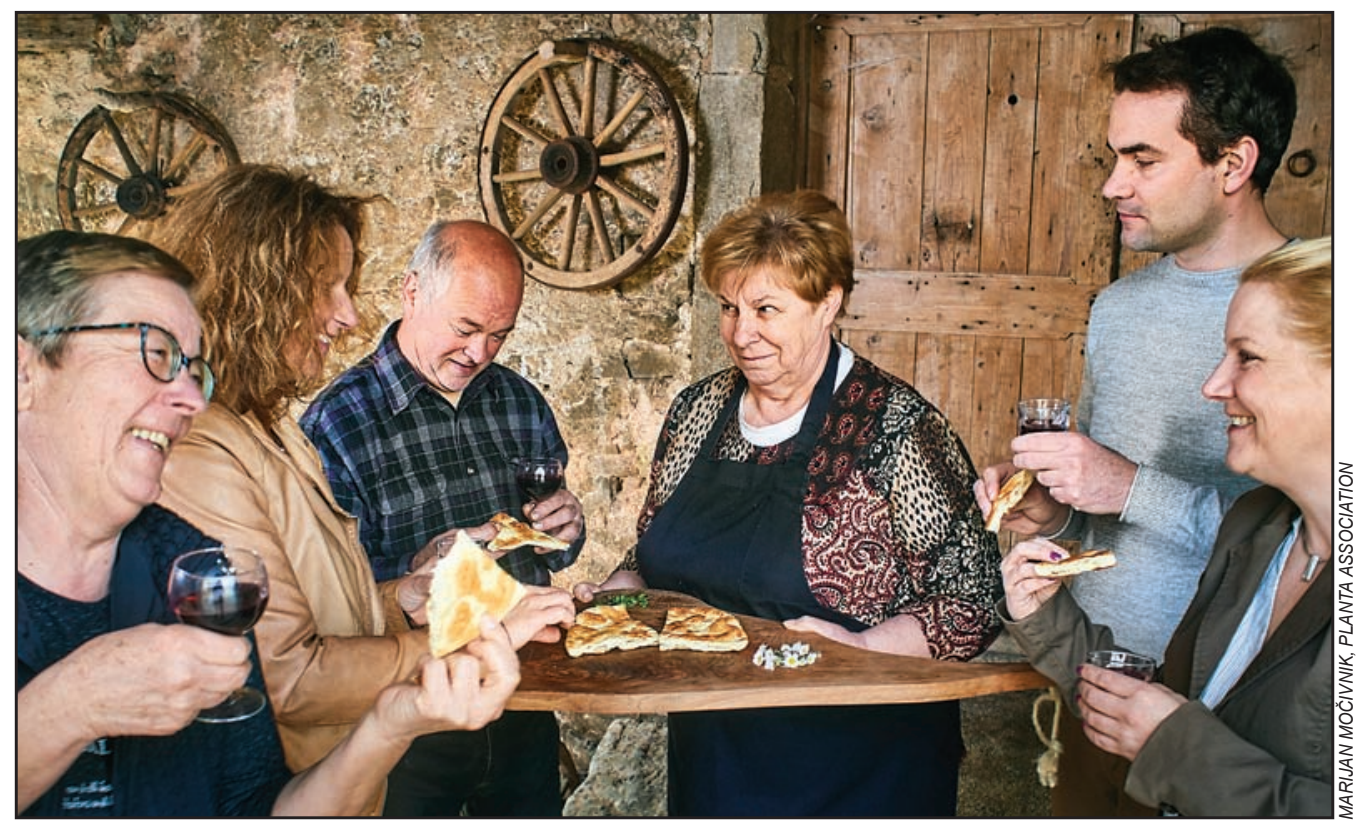

Figure 1: Welcome reception at the Ostrouška Pelicon guest farm, Coljava. 
Many guests find the idea of utilizing a local heritage element previously used in agriculture for serving food appealing. Still, the question arises as to the value and perception of such heritage by the local inhabitants. Farmers who, in the past, manually cut grass and often stuck their hands into the horn would probably have reservations about the new function of the artefact. At the same time, many ethnologists would judge it pejoratively as a folklorism and thus inauthentic (Poljak Istenič 2008; Poljak Istenič 2011).

This leads to the next challenge when designing the luxury tourist package: how to adapt local heritage elements to contemporary use and lifestyles to preserve the authentic flare? According to MacCannell (1976), postmodern tourists are motivated to travel precisely by seeking authenticity. He implanted Goffman's concept of front and back regions (Goffman 1959) into tourist studies and argued that front regions are arranged to deceive the tourists. In contrast, back regions stay closed and thus inspire tourists' curiosity. However, the criteria for luxury experience imply that the providers should offer a glimpse into the »backstage « and even let tourists experience it. Therefore, an important question to reflect upon is how heritage is understood, interpreted, and used for tourism purposes by providers and the local inhabitants who can convince tourists something is authentic. UNESCO has already influenced the understanding of heritage as a mix of tangible and intangible elements that embody the values and meanings of heritage bearers. The respect for those values and attitudes indicates to the tourists that the heritage is authentic. As shown by the example of an ox horn for pouring soup, the help of experts could be beneficial in search of heritage to be used in tourism "authentically«, especially when the usage in an unprecedented way could offend the feelings of heritage bearers.

Some local inhabitants already feel offended because some community members, at least in their opinion, do not treat heritage respectfully, especially the work invested in preserving and presenting it. As they stress, it is thus hard to expect tourists to properly appreciate local heritage if the local inhabitants themselves do not do it:

»We must respect each other and our work. But we will begin to respect our work when we know our history / ... / That is why it is necessary to raise awareness. To make the locals aware so they start appreciating themselves. /.../ [Tourists] come to buy ten litres of wine, and the locals on their initiative also offer slices of prosciutto, homemade bread, and salami, but only charge for ten litres of wine. That means you do not appreciate yourself. That means you put yourself on sale.« (R2)

Another interviewee also expressed that tourists should »learn that [how to make prosciutto and properly offer it] is a real science (GF 2). Prosciutto supposedly has a unique taste when sliced by hand. The tourism providers thus think that instructing their guests on making a thin slice of prosciutto would grant an added value to their offer. The owner of a top restaurant already offers tourists a workshop where they can learn about the entire process of prosciutto production:

»We offer a tour around the place where the prosciutto is made, where you can not only peek through the door but get introduced to the entire process. /.../ We go to the old place where we dry prosciutto, where we have old artefacts in the courtyard, and [we can explain] how pigs were butchered. We also have old tools there. /.../ We also go to the place where we have silhouettes of fresh pork legs [which hang from the ceiling]. We show how to salt them. We explain the whole drying process, from the fresh pork leg to prosciutto.« (R2)

Haute cuisine, in particular, is considered cuisine with added value. It often relies on healthy and local food, promoting "zero kilometres « from the field to the table - or the green criteria for luxury experiences (although STB focuses more on green management than ecological food production). According to the respondents, "zero kilometres « in a Slovenian context indicates a supply chain no further than »up to seventy kilometres«:

»Whatever we need - potatoes, celery tubers, chicory, wild asparagus, or wild plants - we get from the locals. These are local ingredients. /.../ Now, I cannot tell them to grow lettuce for me in the Karst because it needs a lot of water. The farmers [in such cases] send me somewhere else [to a farmer outside the Karst].«(R2)

However, as revealed in the interviews, the biggest problem that food providers in the Karst face is the acquisition of the key ingredient of the Karst cuisine, prosciutto:

»Here we dry meat, here we salt it, that is it. The whole process takes place here in the Karst. But everything else comes from all over Slovenia. /.../ [Therefore], unfortunately, prosciutto cannot be 
a 'zero kilometre' product because we are very strict [with our demands] to have a certain quality of prosciutto. Now we could go to the first farm breeding the pigs. There [the farmer] provides two square metres for pigs [when bred]. But our demand is [using] fifteen square metres per pig, which means they can move a bit. This increases the quality of the meat.« (R2)

One member of the Planta Association (F1) thus decided to breed the only Slovenian autochthonous pig breed - the Krškopolje pig - in the traditional way: the pigs were fed home-grown vegetables and lived outdoors. But a problem arose in dry seasons when there was no food because of the drought; there are unfavourable natural conditions for producing large quantities of home-grown vegetables in the Karst region. Furthermore, this breed takes four years to raise. Thus, the farmer gave up in a few years, angry that the local food companies producing prosciutto do not breed pigs or financially support local farmers. For such reasons, local providers fulfil the concept of "zero kilometres « by using seasonal ingredients. However, this is also why they doubt whether they fulfil the green criteria for a luxury experience.

The majority of the Planta Association members want to continue the culinary tradition of their grandparents because it represents the era before the development of mass tourism and can be characterized as boutique. A few decades before Slovenia's independence:

»... tourists came by bus /.../ tried prosciutto, maybe 'jota' [soup with sauerkraut or turnip], maybe something fried in breadcrumbs, and that was it. Everything, I will say, was done faster. /.../ Later, depending on the place, we saw that this did not work [anymore]. /.../ There were no [more] orders from companies nor union trips, so you had to adapt to the situation.« (R2)

Some providers also make cheese and experiment with adding karst herbs to increase the uniqueness and value of the final product. However, they still ponder how to add value to the tourist experience. In this regard, a suitable place for cheese making would be karst caves, but the problem is, as expressed by the owner of the Karst farm, that:

"... in our country, it is not possible to make cheese in a karst cave, while in Italy, this is possible. In Slovenia, it is not legally possible, although some people park their cars in the cave. It is forbidden to use a natural cave because you must obtain a concession which is granted by the state for the use of state resources." (F2)

Using the natural environment in such a way as suggested above would, in the opinion of the interviewees, definitely contribute to the criteria of uniqueness and differentiate their tourist offer from those in other destinations. However, the question of whether such use of natural resources is sustainable was hard to answer. Interlocutors had difficulty defining the term sustainable and generally associated it with reducing waste (which is also indicated in the green criteria for luxury experiences) as well as consuming local and seasonal ingredients. But the owner of the guest farm highlighted that sustainability also indicates:

»... preserving this tradition of the house. What is produced is also cooked. To stick to these original tastes. And to develop [cuisine] at the same time, so that you 'grow' in the culinary world without stopping." (GF2).

However, from the authors' point of view, sustainability is already embedded in the way of life practiced by members of the Planta Association (Nurse 2006, Labrador and Silberman 2018). Besides buying and consuming locally and relying on ecological production, they also cooperate and help each other, which results in building a close-knit community with a strong local identity. However, until recently, they have not recognized the potential of cooperating with other associations in the Karst. Although they have a good relationship, they have not considered them partners in tourism (Fakin Bajec 2020b). People who safeguard local heritage, master different traditional skills, or are good storytellers could help them with tours, workshops, and events. They can help tourists become "immersed in the life of local people«, as suggested by the criterion of authenticity, and trigger positive emotions to make experiences more memorable.

\subsection{Evaluation of the designed tour according to the top-down criteria}

This chapter first describes the sub-tours of the Kras/Carso Food Tour and then evaluates them according to the criteria of the STB for luxury experiences. However, as the sub-tours are not yet put into practice nor thoroughly described and fixed - flexibility allows them to be adapted according to the tourists' pref- 
erences and time constraints - a thorough evaluation according to all ten criteria was not possible. The assessment was made for a test tour and was adequate to recognize how successful the bottom-up understanding of the criteria's concepts was as well as some gaps to be addressed by the tourism providers should they decide to register the tour under the label Slovenia Unique Experiences.

The Kras/Carso Food Tour consists of several stops in restaurants and on farms offering local cuisine, accompanied by sightseeing of local attractions, presentation of practices, and workshops. Local guides and tourist providers interact with tourists and engage in storytelling to allow them an insight into the local culture. Due to the intensity of the tour (number of visits, quantity of food, duration, etc.), four subtours were designed to highlight the main symbols of local culture and identity: 1) herbs, 2) prosciutto, 3 ) winemaking, as well as the ability of local chefs to include them in 4) high-end cuisine. The sub-tours described below promote a distinctive food or haute cuisine while the accompanying sightseeing is left to the tourists' desires and thus not included as a fixed element.

The spring tour »Karst herbs - relaxation and enjoyment of flowering karst meadows and commons « raises awareness of the botanical diversity of the Karst. Karst spring cuisine is marked by the early fresh herbs and has been characterized by herbal frtalja (omelette; Figure 1), dandelion salad, and vegetable minestrone. For the tourists, the marenda (morning snack) is served in an herbal garden to present how local people ate during times of major farm work. Besides enjoying food, the guests learn about local wild plants, the skills of picking herbs, and the preparation of herbal soaps, ointments, and tinctures.

The second tour, "Karst prosciutto - a culinary treasure as the product of years of experience and the natural curiosities of Karst, " revolves around an essential element in Karst cuisine - dried meat products, especially prosciutto. The guests get to know the entire process of salting and drying prosciutto and learn how to best slice it by hand.

The third tour, "Karst winemaking - climate, red soil, knowledge and hardworking people«, is dedicated explicitly to Teran, the most well-known Karst wine (Figure 2). It revolves around the history of viticulture in the Karst as well as the production of Teran and white varieties of wine. The providers invite guests to their wine cellars. They taste selected wines and learn about Karst cellaring and the most important Karst celebration linked to wine, bendima (the grape harvest).

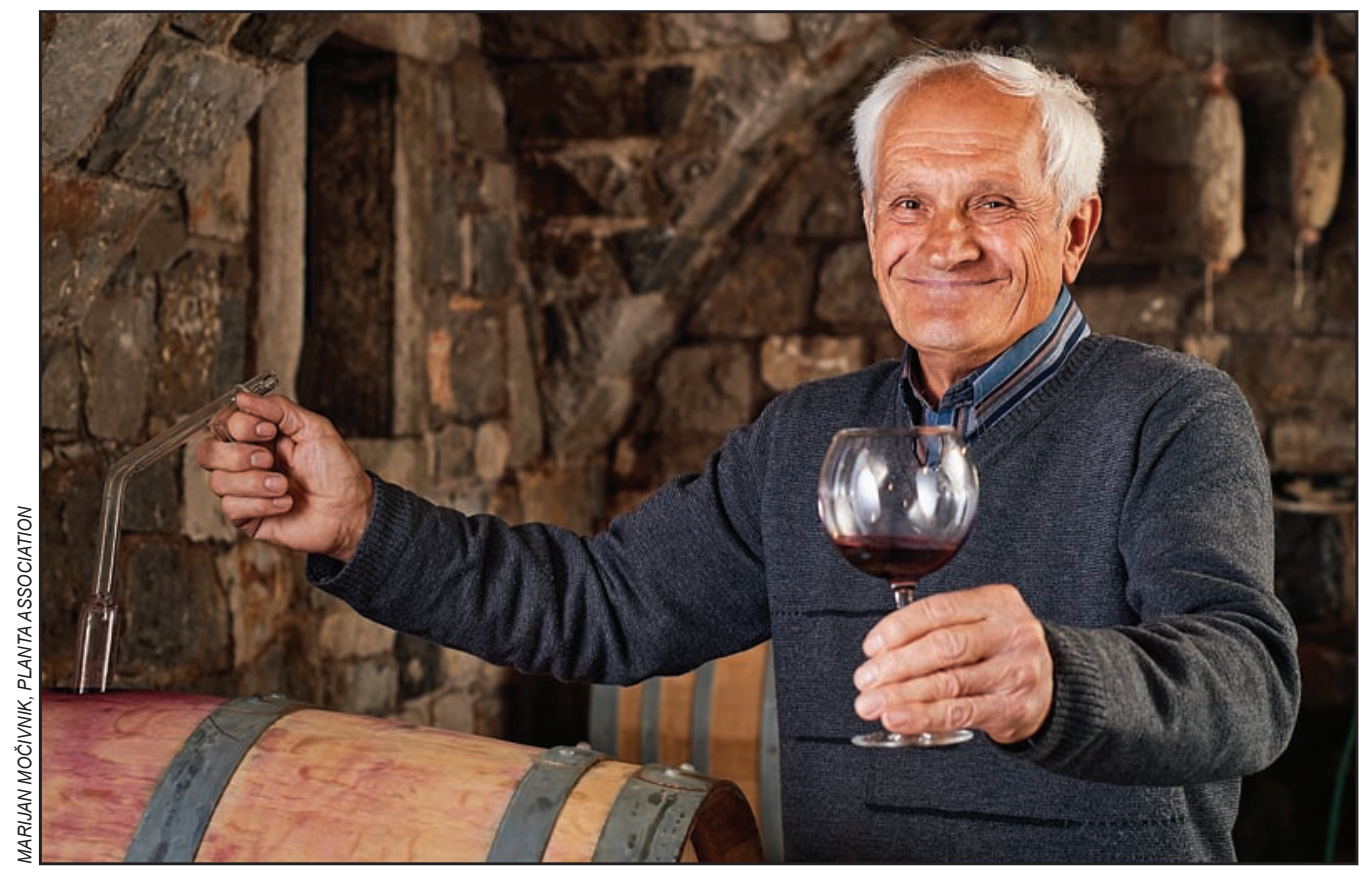

Figure 2: Presenting Teran wine in the cellar at the Buntovi farm, Škrbina. 


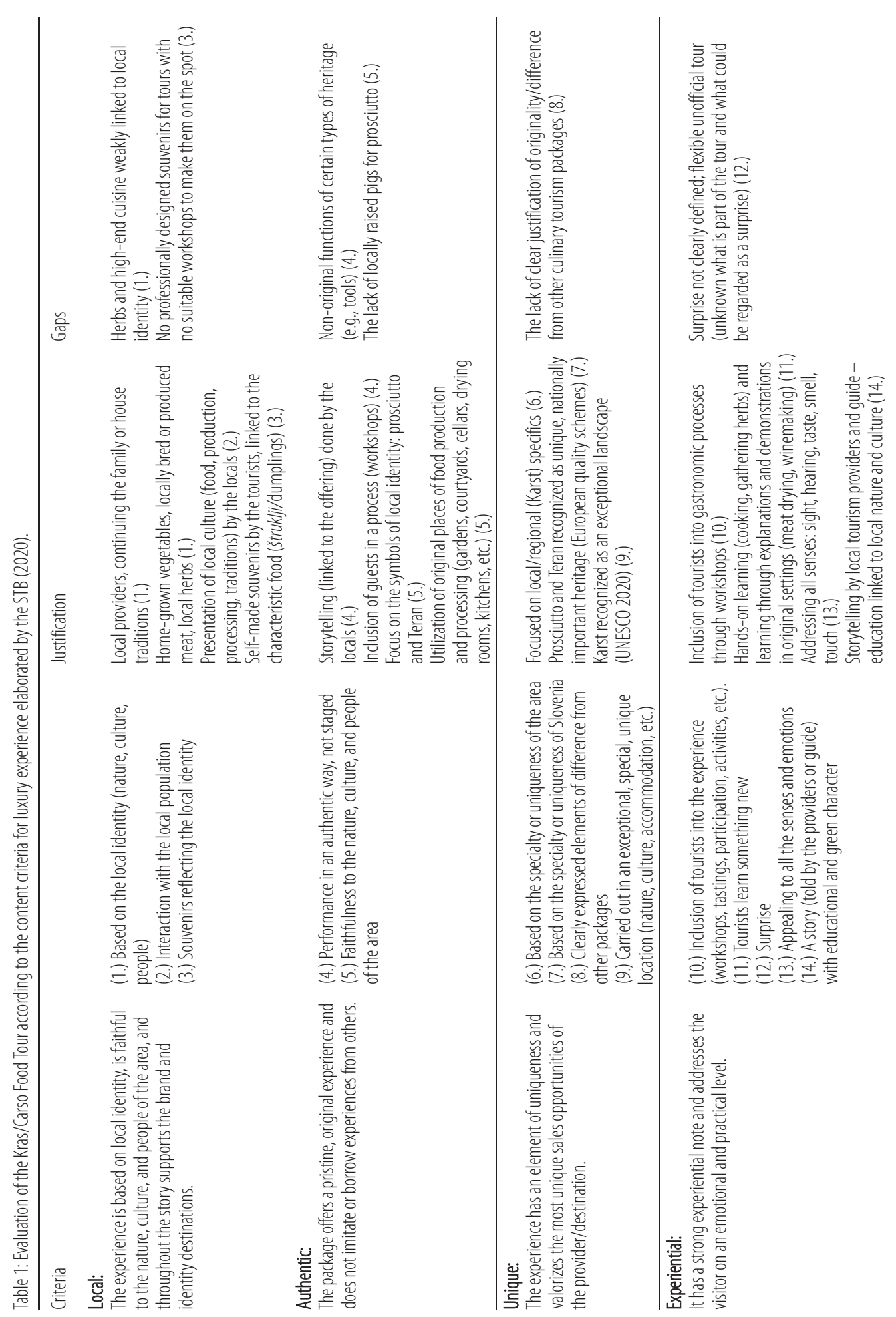




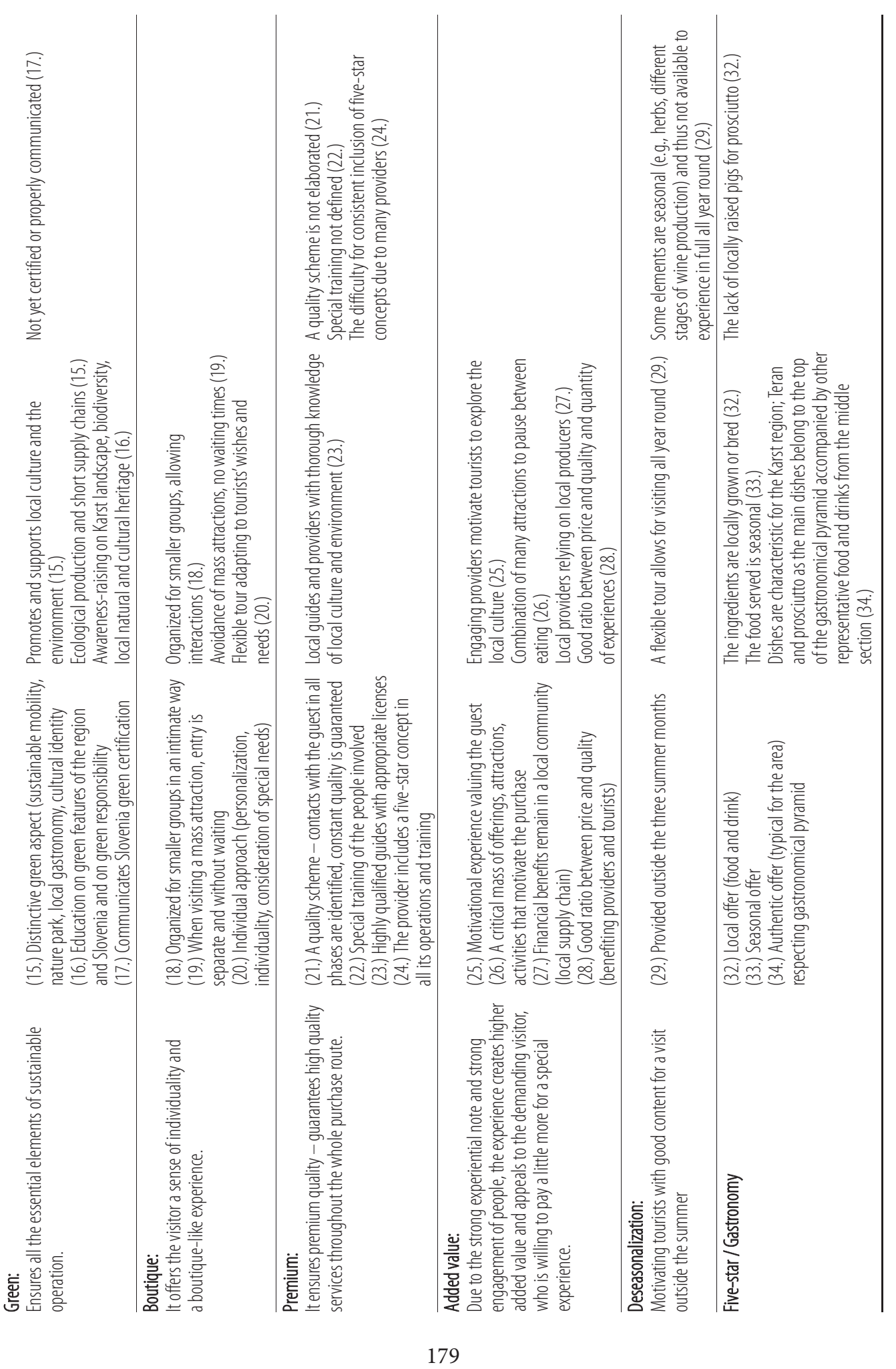


The fourth tour, "Karst high-end cuisine - where the tradition of classic inns encounters contemporary creativity «, is based on the old catering business already well developed in the $19^{\text {th }}$ century. It promotes local flavours and ingredients (also from the other three tours) as the critical components of haute cuisine. The boutique and authenticity of the offer are further enriched by tasting menus, artistic arrangements of food, wine accompaniment, additional tastings, and the time that chefs and waiters dedicate to the guests to teach them about tradition and modernity through top-quality food.

Based on the active participation in the test tour, the evaluation (Table 1) reveals that the tours fulfil most of the content criteria for a luxury experience. We can thus conclude that the tourism providers, despite struggling to understand the national criteria for luxury experiences (see Chapter 3.1), succeeded in implementing them in a tour design in line with the national tourism strategy - with the help of experts familiar with academic discourses and local culture who discussed different conceptual meanings with them and debated over the use of local traditions and heritage practices for tourism purposes.

However, the authors also detected possible gaps which could be addressed to increase the added value of the Kras/Carso Food Tour and be used by the tourism providers and organizations to improve their product. The following assessment thus serves to fulfil the applied aim of the paper.

The effort of the tourism providers should be devoted to linking the herbs and haute cuisine more convincingly to the local identity and the selection of souvenirs not made by the tourists on the spot. As some ingredients (herbs) and some stages of food production (e.g., of wine) are seasonal, the tours need to define several ways to promote them in all seasons. The same applies to weather; providers need to have a backup plan for outdoor activities. The only issue which cannot be solved is the lack of locally-bred pigs for prosciutto; however, as this product already earned a Protected Geographical Indication label, its local character is not disputed. Special attention must also be given to the use of cultural heritage for new purposes, as it can quickly destroy the tourists' perception of authenticity. Furthermore, as the tour is not defined (and described) in detail, it is hard to validate what is supposed to be a surprise for the tourists, recommended to be provided for fulfilling the experiential criteria.

Other deficiencies of the packages mainly concern the background work not directly linked to the tourist promotion. It would be beneficial to conduct a study of similar food tours to underscore the tour's originality. The providers should also strive to earn any of the Slovenia Green certificates (at least the Green Cuisine) and elaborate on promoting this brand and communicating it to tourists. The most problematic criterion is uniqueness, which guarantees high-quality services throughout the whole purchase route. The problem lies in the absence of a powerful organization that would market the tour. Despite the good impression of the offering's quality gained on the test tour, the providers have not yet set up a quality scheme to ensure a consistent level of service, nor have they organized special training for all the people involved. Furthermore - especially in light of the considerable number of tourism providers - the lack of strong organizational and promotional support also hinders the consistent inclusion of luxury criteria (or concepts) in their actions and consequent improvement of their services.

\subsection{General recommendations for tourism providers and tourist sector}

On the one hand, the evaluation results provided in the previous chapter can be used more or less only on the local level, i.e., by the Karst tourism providers. On the other hand, the general assessment indicates what tourism organizations anywhere should give their attention to.

We recommend them to demonstrate strong links to local identity; figure out how to overcome the seasonality of the offers; take into account changing weather conditions and adapt the tour accordingly; and carefully plan the use of cultural heritage in tourism together with their bearers. The inclusion of local heritage can effectively contribute to the added value of the tour. Still, if the local way of life is not interpreted sensitively and authentically, it can hinder the involvement of the local inhabitants - key for the perception of the authenticity - as well as devalue heritage (Bogataj 1998). It would also be helpful for tourism providers to familiarize themselves with tourism strategies and labels before designing the tour, as this would make them aware of the quality schemes, certifications, training of staff, and other operations which do not directly involve the tourists but are necessary for a luxury product. This would make branding the product easier when put into practice. They could also analyse similar tours to avoid being one of many providers of the same experience. Strong organizational and promotional support is crucial for successfully implementing their tourism products; ensuring it already in the planning phase would help them in the process 
and later to develop supplemental tourism activities. And to stress again, it is advised to engage experts in case they have difficulty understanding top-down recommendations and criteria.

\section{Conclusion}

"A destination of five-star experiences « is the current, luxury-oriented vision of Slovenia in the tourism context, which has demonstrated the popularity of »the luxury turn « (Bellini and Resnick 2018). It has been realized through the activities of the STB, including branding tourism products under the label Slovenia Unique Experiences. The criteria ensure that the tours are of premium quality and guarantee the tourists »experiencing a story in a very personal way, at its original scene, in touch with locals, in a way that has not been copied from elsewhere and is in line with the sustainable principles in tourism « (Internet 4). On the other hand, the luxury concept and promotional support of the STB also motivate tourism providers to develop or adapt existing tourism offerings according to the criteria for winning the Slovenia Unique Experiences label, as has been the case of the Kras/Carso food tour presented in this paper.

Top-down approaches often fail to translate into productive, sustainable, and long-lasting activities of the communities they address (Fakin Bajec 2020c). The criteria for luxury tourism products are thoroughly explained by the STB and seem to be applied easily to tourism products when one is acquainted with the terms and concepts used as well as the history, heritage, and traditions of the area in question. However, the ethnographic analysis presented in the paper revealed that the concepts of authenticity, uniqueness, local, etc. - as well as the core term of experience - are subject to very personal interpretations. This poses a particular challenge when designing luxury tours, especially concerning the use of heritage for »authenticating " the experience. The researchers involved in the MEDFEST project, including the authors, thus made a considerable effort to discuss with tourism providers not only their ideas, wishes, knowledge, shortcomings, and strengths but also the meaning of the terms and concepts. The mediation of experts familiar with the terminology and theory deriving from academic discourses proved beneficial, as shown by the evaluation of the food tour according to the content criteria. As it revealed only minor shortcomings, we can conclude that the intervention of the experts (i.e., researchers) in designing the tour crucially contributed to the understanding of the criteria for luxury tourism products and consequently to the successful tour design and its implementation. In cases where experts do not get involved, local providers - in the authors' experience - often shy away from designing luxury tourism products despite the great potential for their realization.

The authors' analysis of the case study, in which top-down criteria and bottom-up interpretations were juxtaposed, proves that an integrated, multi-level participatory approach (Poljak Istenič 2019; Fakin Bajec 2020d) is not only successful but also urgently needed for the successful development of luxury tourism. In this particular case, it led to a food tour design with the potential to obtain the label Slovenia Unique Experiences, which would significantly improve its promotion outside the regional context. Furthermore, local traditions and heritage practices, usually perceived as too simple and not sufficiently elite, proved crucial for the luxurification of the experience, fulfilling the criteria of originality and authenticity, uniqueness, and being boutique - although the process was also heavily debated due to contested views on the use of local culture for tourism purposes.

The paper also shows why bottom-up perspectives are crucial for the analysis of the tourism discourse. Strategic documents for tourism development rely on academic concepts, but since communities or other tourism providers generally do not have sufficient knowledge to understand them, the translation of the strategic or action plans in practice often fails to produce desirable outcomes. This paper has revealed the need to consider a bottom-up understanding of luxury tourism to ensure its development also outside elite areas and services. When expert mediation is provided, luxury tourism can flourish in rural areas, use unremarkable local heritage, or rely on people's traditions.

ACKNOWLEDGEMENTS: The authors acknowledge the financial support of the European Regional Development Fund for the project MEDFEST: MED Culinary heritage experiences: how to create sustainable tourist destinations (Interreg Mediterranean, 2016-2019) and of the Slovenian Research Agency for the research programmes Historical interpretations of the $20^{\text {th }}$ century (P6-0347) and Cultural Spaces and Practices: Ethnology and Folklore Studies (P6-0088) as well as the research projects The Invisible Life of 
Waste: Development of an Ethnography-based Solution for Waste Management in Households (L6-9364, for research on green management) and Young entrepreneurs in times of uncertainty and accelerated optimism: an ethnological study of entrepreneurship and ethics of young people in modern-day Slovenia (J6-1804, for research on creative entrepreneurship in tourism).

Special thanks go to researchers involved in the MEDFEST project, particularly Nika Razpotnik Visković for project coordination and Mateja Šmid Hribar for leading the Karst region's pilot action; they participated in interviewing and transcriptions. We also thank Primož Pipan for his cooperation in ethnographic research.

\section{References}

Antony, R., Henry, J. 2005: The Lonely Planet Guide to experimental travel. Melbourne.

Bajuk Senčar, T. 2005: Kultura turizma. Ljubljana.

Barrère, C., Bonnard, Q., Chossat, V. 2014: Luxury tourism and luxury gastronomy: A new Holy Alliance based on heritage? Territoire en mouvement Revue de géographie et aménagement 21. DOI: https://doi.org/ $10.4000 /$ tem. 2267

Batat, W. 2020: The role of luxury gastronomy in culinary tourism: An ethnographic study of Michelin-Starred restaurants in France. International Journal of Tourism Research 23-2. DOI: https://doi.org/10.1002/jtr.2372

Batat, W., Frochot, I. 2014: Towards an experiential approach in tourism studies. The Routledge Handbook of Tourism Marketing. London, New York. DOI: https://doi.org/10.4324/9781315858265.ch9

Bellini, N., Resnick, E. 2018: The luxury turn in wine tourism: Still good for local development? Gastronomy and Local Development: The Quality of Products, Places and Experiences. London, New York. DOI: https://doi.org/10.4324/9781315188713-12

Bogataj, J. 1998: Smo kaj šegavi? Leto šeg in navad na Slovenskem. Ljubljana.

Ciglič, R., Hrvatin, M., Komac, B., Perko, D. 2012: Karst as a criterion for defining areas less suitable for agriculture. Acta geographica Slovenica 52-1. DOI: https://doi.org/10.3986/AGS52103

Cohen, E. 1979: Rethinking the sociology of tourism. Annals of Tourism Research 6-1. DOI: https://doi.org/ 10.1016/0160-7383(79)90092-6

Cohen, E. 1988: Authenticity and commoditization in tourism. Annals of Tourism Research 15-3. DOI: https://doi.org/10.1016/0160-7383(88)90028-x

Conrady, R., Ruetz, D., Aeberhard, M. 2020: Luxury tourism: Market trends, changing paradigms, and best practices. DOI: https://doi.org/10.1007/978-3-030-59893-8

CPOEF - Center poslovne odličnosti Ekonomske fakultete: Analiza strateških tokov gostov na destinaciji Kras z vključenim razvojnim in trženjskim načrtom za destinacijo Kras, za obdobje 2019-2024. Ljubljana, 2018.

Curtin, S. 2005: Nature, wild animals and tourism: An experiential view. Journal of Ecotourism 4-1. DOI: https://doi.org/10.1080/14724040508668434

de Bruin A., Jelinčić, D. A. 2016: Towards extending creative tourism: Participatory experience tourism. Tourism Review 71-1. DOI: https://doi.org/10.1108/TR-05-2015-0018

Du Cros, H., McKercher, B. 2020: Cultural tourism. London. DOI: https://doi.org/10.4324/9780429277498

Fakin Bajec, J. 2011: Procesi ustvarjanja kulturne dediščine: Kraševci med tradicijo in izzivi sodobne družbe. Ljubljana.

Fakin Bajec, J. 2015: Interpretations of stone in the Karst yesterday, today and tomorrow. Stone Narratives. Heritage, Mobility, Performance. Koper.

Fakin Bajec, J. 2020a: Community-sourced cultural heritage valorization model. Ljubljana. DOI: https://doi.org/10.3986/9789610504450

Fakin Bajec, J. 2020b: Procesi ustvarjanja kulturne dediščine: Na razpotju med neoliberalizmom in prostovoljstvom v okviru dediščinskih društev. Etnolog 30.

Fakin Bajec, J. 2020c: Vključevanje skupnosti v razvoj in upravljanje kulturne dediščine v aplikativnih evropskih projektih. Glasnik Slovenskega etnološkega društva 60-1.

Fakin Bajec, J. 2020d: An integrated approach to the revitalisation, safeguarding and management of cultural heritage: How to establish a durable and active local group of stakeholders. Annales, Series Historia et Sociologia 30-2. DOI: https://doi.org/10.19233/ASHS.2020.17 
Fennell, D. A. 2020: Ecotourism. London. DOI: https://doi.org/10.4324/9780429346293

Goffman, E. 1959: The presentation of self in everyday life. New York.

Holbrook, M. B., Hirschman, E. C. 1982: The experiential aspects of consumption: Fantasies, feelings and fun. Journal of Consumer Research 9-2. DOI: https://doi.org/10.1086/208906

Internet 1: https://medfest.interreg-med.eu/ (3. 8. 2020).

Internet 2: https://www.krascarso-foodtour.com/ (13. 8. 2020).

Internet 3: https://www.slovenia.info/uploads/5_zvezdicna_dozivetja/k01_-_poziv_-_slovenia_ue_-_pilotni-junij-2018.pdf (22. 4. 2021).

Internet 4: https://www.slovenia.info/en/slovenia-unique-experiences (30. 7. 2020).

Jelinčić, D. A., Senkić, M. 2017: Creating a heritage tourism experience: The power of the senses. Etnološka tribina 47-40. DOI: https://doi.org/10.15378/1848-9540.2017.40.03

Kirshenblatt-Gimblett, B. 1998: Destination culture. Tourism, museums and heritage. Berkeley.

Kozorog, M. 2009: Antropologija turistične destinacije v nastajanju: Prostor, festivali in lokalna identiteta na Tolminskem. Ljubljana.

Kozorog, M., Poljak Istenič, S. 2013: Triglavski narodni park v horizontu rekreacijskega avanturizma. Traditiones 42-2. DOI: https://doi.org/10.3986/traditio2013420206

Kumer, P., Pipan, P., Šmid Hribar, M., Razpotnik Visković, N. 2019: The role of actors' cooperation, local anchoring and innovation in creating culinary tourism experiences in the rural Slovenian Mediterranean. Geografski vestnik 91-2. DOI: https://doi.org/10.3986/gv91201

Labrador, A. M., Silberman, N. A. 2018: The Oxford handbook of public heritage theory and practice. New York. DOI: https://doi.org/10.1093/oxfordhb/9780190676315.001.0001

Lew, A. A. 2011: Understanding experiential authenticity through the best tourism places. Tourism Geographies 13-4. DOI: https://doi.org/10.1080/14616688.2011.588245

MacCannell, D. 1976: The tourist: A new theory of the leisure class. New York.

Manley, A., Silk, M., Chung, C., Wang, Y. W., Bailey, R. 2020: Chinese perceptions of overseas cultural heritage: Emotive existential authenticity, exoticism and experiential tourism. Leisure Sciences. DOI: https://doi.org/10.1080/01490400.2020.1817200

McGladdery, C. A., Lubbe, B. A. 2017: Rethinking educational tourism: Proposing a new model and future directions. Tourism Review 72-3. DOI: https://doi.org/10.1108/tr-03-2017-0055

MGRT - Ministry of economic development and technology: Strategy for the sustainable growth of Slovenian tourism 2017-2021. Ljubljana, 2017.

Nared, J., Bole, D. 2020: Participatory research on heritage-and culture-based development: A perspective from South-East Europe. Participatory Research and Planning in Practice. Cham. DOI: https://doi.org/ 10.1007/978-3-030-28014-7_7

Novak, M. 2018: 5-zvezdična doživetja - Slovenia Unique Experience: Pojasnitev koncepta (zakaj, kako, kaj). Powerpoint presentation. Internet: https://www.slovenia.info/uploads/dokumenti/zelena-shema/ 2018_gradiva/zeleni_dan/poziv_za_5-zvezdicna_dozivetja_misa_novak_zeleni_dan_28.5.18.pdf (31. 7. 2020).

Novak, M. 2019: Slovenia unique experiences. Internet: https://slovenia.si/excellence/slovenia-unique-experiences/ (31. 7. 2020).

Nurse, K. 2006: Culture as the fourth pillar of sustainable development. Internet: http://placemakers. wdfiles.com/local—files/theoretical-analysis-examined/Cultureas4thPillarSD.pdf (15. 1. 2021).

Pearce, P. L., Moscardo, G. M. 1986: The concept of authenticity in tourist experiences. The Australian and New Zealand Journal of Sociology 22-1. DOI: https://doi.org/10.1177/144078338602200107

Pine, B. J., Gilmore, J. H. 1998: Welcome to the experience economy. Harvard Business Review 76-4.

Pine, B. J., Gilmore, J. H. 1999: The experience economy. Boston.

Poljak Istenič, S. 2008: Customs and traditions as folklorism. Traditiones 37-2. DOI: https://doi.org/ 10.3986/Traditio2008370204

Poljak Istenič, S. 2011: Texts and Contexts of Folklorism. Traditiones 40-3. DOI: https://doi.org/10.3986/ Traditio2011400304

Poljak Istenič, S. 2013: Tradicija v sodobnosti: Janče - zeleni prag Ljubljane. Ljubljana.

Poljak Istenič, S. 2015: Kolo kot akter ustvarjalne urbane regeneracije. Glasnik Slovenskega etnološkega društva 55-3,4. 
Poljak Istenič, S. 2016: Reviving public spaces through cycling and gardening: Ljubljana - European Green Capital 2016. Etnološka tribina 46-39. DOI: https://doi.org/10.15378/1848-9540.2016.39.06

Poljak Istenič, S. 2018: Green resistance or reproduction of neoliberal politics? Grassroots collaborative practices in Slovenia's »Green Capital« Ljubljana. Ethnologia Europaea 48-1. DOI: https://doi.org/ 10.16995/ee.1949

Poljak Istenič, S. 2019: Participatory urbanism: Creative interventions for sustainable development. Acta geographica Slovenica 59-1. DOI: https://doi.org/10.3986/AGS.5142

Prentice, R. C., Witt, S. F., Hamer, C. 1998: Tourism as an experience: The case of heritage parks. Annals of Tourism Research 25-1. DOI: https://doi.org/10.1016/s0160-7383(98)00084-x

Richards, G. 1996: Cultural tourism in Europe. Wallingford.

Richards, G. 2011: Creativity and tourism: The state of the art. Annals of Tourism Research, 38-4. DOI: https://doi.org/10.1016/j.annals.2011.07.008

Richards, G. 2020: Designing creative places: The role of creative tourism. Annals of Tourism Research 85. DOI: https://doi.org/10.1016/j.annals.2020.102922

Rickly, J. M., McCabe, S. 2017: Authenticity for tourism design and experience. Design Science in Tourism. Tourism on the Verge. Cham. DOI: https://doi.org/10.1007/978-3-319-42773-7_5

Ritchie, B. W., Carr, N., Cooper, C. P. 2003: Managing educational tourism. Clevedon, Buffalo, Toronto, Sydney.

Schulze, G. 1992: Die Erlebnisgesellschaft: Kultursoziologie der Gegenwart. Frankfurt, New York.

Smith, W. L. 2006: Experiential tourism around the world and at home: Definitions and standards. International Journal of Services and Standards 2-1. DOI: https://doi.org/10.1504/ijss.2006.008156

Sotiriadis, M. 2017: Experiential dimensions and their influence on behavioral intentions within the context of nature-based tourism. Tourism and hospitality management 23-1. DOI: https://doi.org/ 10.20867/thm.23.1.7

STB - Slovenian Tourist Board: Postopkovnik o ocenjevanju doživetij Slovenia Unique Experiences in pogojih podeljevanja pravice do uporabe znamke Slovenia Unique Experiences. Internet: https://www.slovenia.info/uploads/5_zvezdicna_dozivetja/poziv_2020/postopkovnik_slovenia_unique_ex perience_18_02_2020.pdf (12.8.2020).

Stronza, A. 2001: Anthropology of tourism: Forging new ground for ecotourism and other alternatives. Annual Review of Anthropology 30. DOI: https://doi.org/10.1146/annurev.anthro.30.1.261

Tan, S. K., Kung, S. F., Luh, D. B. 2013: A model of 'creative experience' in creative tourism. Annals of Tourism Research 41. DOI: https://doi.org/10.1016/j.annals.2012.12.002

Timothy D. J. 2020: Cultural heritage and tourism: An introduction. Bristol. DOI: https://doi.org/10.21832/ timoth7710

Timothy, D. J., Boyd, S. B. 2003: Heritage tourism. Essex.

Toffler, A. 1970: Future shock. New York.

Topole, M., Pipan, P. 2020: Between traditions and innovations. Culinary boutique tourism in the hinterland of Mediterranean tourist destinations. Traditiones 49-3. DOI: https://doi.org/10.3986/Traditio2020490305

UNESCO - United Nations educational, scientific and cultural organization: Tentative lists - Classical Karst. Internet: https://whc.unesco.org/en/tentativelists/6072/ (6. 8. 2020).

Wang, N. 1999: Rethinking authenticity in tourism experience. Annals of Tourism Research 26-2. DOI: https://doi.org/10.1016/s0160-7383(98)00103-0

Yeoman, I. 2008: Tomorrow's tourist: Scenarios and trends. London, New York. DOI: https://doi.org/ $10.4324 / 9780080878904$ 